DOI: https://doi.org/10.24144/2409-6857.2018.1(51).43-46

УДК 339.9 - 044.22: $314.116-026.24$

Кальницька М. А., Стецишин В. Р.

\title{
ДЕМОГРАФІЧНА КРИЗА ЯК СКЛАДОВА ЕКОНОМІЧНО РОЗВИНУТИХ КРАЇН
}

\begin{abstract}
У иій статті розглядається світова демографічна криза як складова економічно розвинутих країн. Досліджуються причини ї̈ виникнення та особливості прояву у різних краӥнах. Аналізуються традиційні иляхи подолання демографічної кризи, зокрема демографічна політика держави, економічне стимулювання народжуваності та покращення демографічної ситуації за рахунок збільшення міграційних потоків у краӥну. Встановлюються труднощі, які виникають під час вирішення иієё проблеми, та позитивні $i$ негативні наслідки, щзо можуть виникнути при діях або, навпаки, бездіяльності держави. Пропонуються також власні альтернативи вирішення світової демографічної кризи як для розвинутих держав, так і для країн третього світу.
\end{abstract}

Ключові слова: глобалізачія, глобальні проблеми, демографія, демографічна криза, демографічна політика.

Постановка проблеми. Із появою першої людини суспільно поступово розвивалося, перебуваючи під впливом багатьох тенденцій. Основними є: модернізація, глобалізація та інформатизація. Вони є невід'ємними складовими еволюції людини, проте їх тривалість та інтенсивність завжди відрізнялася. Сьогодні свого апогею сягнула глобалізація, оскільки внаслідок посилення міжнародного поділу праці вона фактично зробила економіки країн тісно переплетеними та взаємозалежними. Однак у той же час це породило низку проблем, вирішення котрих залежить від спільних зусиль всіх країн світу. Світова демографічна криза є однією з таких проблем.

Сьогодні показники рівня народжуваності поступово падають, але водночас знижується рівень смертності і зростає тривалість життя населення. Така ситуація $є$ характерною для всіх розвинутих країн, які переходять до постіндустріальної фази розвитку. У той час, коли у високорозвинутих країнах зменшується частка молоді, у слабо розвинутих вона поступово збільшується. Це призводить до старіння нації та збільшення частки неосвіченого населення. Тож демографічна криза потребує нагального вирішення, оскільки це становить загрозу подальшому економічному розвитку країн.

Аналіз останніх досліджень та публікацій. Загострення демографічної проблеми - це той чинник, який призведе до втрати багатьма країнами своїх провідних позицій, тому вона по-

(C) Кальницька Марина Анатоліївна, к.е.н., доцент кафедри міжнародної політики, ДВНЗ «Ужгордський національний університет», м. Ужгород, тел.: 0503178746, e-mail: marinakalnicka@gmail.com

Стецишин Владислава Романівна, студентка, ДВНЗ «Ужгородський національний університет», м. Ужгород, тел.: 0990971855, e-mail: vladastecishin@ gmail.com требує деталізованого вивчення та правильного, раціонального шляху вирішення. Дослідженням цього питання присвячено праці багатьох вітчизняних науковців. Зокрема, Л.С. Дорошенко визначив такі основні ознаки глобалізації як скорочення чисельності населення, перевищення рівня смертності над рівнем народжуваності, негативні зрушення в рівні населення. [2] В. А. Борисов зосередив увагу на основних особливостях демографічної кризи сьогодні: економічно розвинені країни давно вже минули другу фазу демографічного переходу і вступили у третю, для якої характерним $€$ зниження показників природнього приросту населення. [1] О.В. Макарова встановила залежність між проблемою старіння нації та фінансовими системами країн, оскільки непомірно великі суми потребуватимуть пенсійна система і система медичної допомоги. [5] Н.О. Власенко у своїх працях зосередив увагу на процесах демографічного переходу від високих темпів приросту чисельності населення, до ситуацій, коли рівень смертності знижується, продовжується тривалість життя, але при цьому народжуваність падає. [3]

Проте, незважаючи на значну кількість фундаментальних досліджень безлічі авторів та дій збоку держави, проблема світової демографічної кризи продовжує поступово загострюватися, тому ii вирішення потребує всебічного опису всіх можливих чинників.

Формулювання цілей статті. Метою статті $\epsilon$ вивчення світової демографічної кризи, розгляд основних іï чинників, шляхів вирішення проблеми та тісного зв'язку між нею та іншими глобальними проблемами.

Опис основного матеріалу досліджень. 3 точки зору теорії демографічна криза - різке погіршення розвитку населення, зумовлене процесами депопуляції. Її основними ознаками $є$ 
скорочення чисельності населення, перевищення рівня смертності над рівнем народжуваності та негативні зрушення у показниках рівня населення. [2]

Протягом свого розвитку всі країни неодмінно проходять процес демографічного переходу, коли високі темпи приросту чисельності населення поступово зводяться до ситуаціі, коли рівень смертності знижується, подовжується тривалість життя, але при цьому народжуваність падає. Як результат, спостерігається або невеликий приріст, або зменшення чисельності населення. [3]

Проте падіння рівня народжуваності у сучасному світі 3 точки зору демографічного переходу можна вважати універсальним процесом, характерним для усіх країн, які переходять як до індустріальної, так i до постіндустріальної фази розвитку.

Поступове зниження рівня народжуваності у глобальному масштабі розпочалося ще у 60-х роках минулого століття. Однак доволі тривалий час (з початку 60-х до початку 90-х років) ці показники мали відносно стабільні значення. [5]

Але сьогодні, з пришвидшеними темпами розвитку суспільства, зміною пріоритетів молодого населення, ментальними трансформаціями показники рівня народжуваності почали стрімко падати, породивши нову глобальну проблему демографічну кризу, яка потребує негайного вирішення.

У даний час світова демографічна ситуація має свої особливості. Економічно розвинені країни давно вже минули другу фазу демографічного переходу i вступили у третю, для якої характерним $є$ зниження показників природнього приросту населення. До недавнього часу істотних відмінностей у цих групах не спостерігалося. Однак останнім часом в цій групі країн почала відбуватися досить сильна диференціація. Тому цю групу поділяють на три підгрупи. [1] 1. Країни в яких ще зберігається досить сприятлива демографічна обстановка. Для них характерним $є$ збереження середніх показників народжуваності та природнього приросту населення. До цієї групи відносять США, Канаду, Нідерланди, Норвегію, Францію, Швейцарію, де середньорічний приріст населення перебуває на рівні 0,3-0,5 \%. 2. Країни, в яких вже фактично не забезпечується розширене відтворення населення. До них відносяться в основному країни Європи, де сумарний коефіцієнт народжуваності ще в середині 90-х років знизився до показника 1,5. Це Австрія, Бельгія, Іспанія, Португалія, Данія, Хорватія, Ірландія. Деякі ці країни ще мають мінімальне перевищення народжуваності над смертністю. Інші ж стали країнами 3 нульовим приростом населення. 3. Країни 3 від'ємним приростом населення. Сумарний коефіцієнт народжуваності гранично низький. Число таких країн з “мінусовим" приростом населення тільки 1990-2000 рр.. зросла 33 до 15. Всі вони переважно знаходяться в Свропі. У першу чергу для них характерне швидке зниження коефіцієнту народжуваності, що веде до зменшення у частці населення осіб молодшого віку. Це явище демографи називають старінням знизу. [8]

Ця проблема спричинена як соціальними, так i економічними чинниками. Основною першопричиною є трансформація інституту сім’і. У минулому основою була патріархальна сім'я, коли роль годувальника відводилися чоловіку. Однак, сьогодні сім'я стала ліберальною, і всі члени однаково прагнуть до самореалізації.

Така трансформація зумовлена перш за все 3 посиленням гендерної рівності у суспільному житті. Сьогодні жінка прагне до фінансової незалежності, що можна пояснити, на нашу думку, двома ключовими факторами. По-перше, трансформація ментальності у суспільстві створила новий критерій успіху, який полягає у побудові вдалої кар'єри. А по-друге, у зв'язку 3 постійним загостренням економічної ситуації у країнах жінки також починають переймати роль годувальників у сім’ї та іноді працюють на рівні 3 чоловіками.

3 іншого боку, подружні пари при прийнятті рішення щодо збільшення своєї сім’ї часто обмежуються заведенням лише однієї дитини. Цей вибір можна вважати стратегічним, оскільки оцінюються переваги, які можуть бути від дітей та витрати, які неодмінно збільшаться. Тому 3 метою забезпечення певного рівня достатку, хорошого та якісного догляду за дитиною, надання їй відповідної освіти майбутні батьки створюють невеликі сім’і.

Ці чинники є ключовими у процесі зниження народжуваності, але також варто не забувати про сучасні тенденції ментальності. Зокрема сьогодні суспільство стало більш відкритим, відвертим. Люди 3 нетрадиційними сексуальними орієнтаціями отримали більше прав та свобод, вони створюють сім'ї, але позбавлені змоги нормально заводити дітей, що у свою чергу вносить свою невеличку частку до зниження рівня народжуваності. Також варто не забувати, що зростаючи у такій сім’ї, дитина може піддаватися дискримінації з боку інших людей. Тому з метою уникнення подібних ситуацій люди 3 нетрадиційною сексуальною орієнтацією часто зовсім відмовляються від створення повноцінної сім’ї. 
Тож недивно, що населення економічно розвинених країн стрімко старіє, i ця ситуація становить серйозну загрозу економічному розвитку. Проблема старіння нації стає з кожним роком все більш глобальнішою і потребує все більших і більших затрат. Для країн Європи, Північної Америки, Японії, які стоять на порозі вікової кризи, старіння населення погрожує зруйнувати фінансові системи цих країн, оскільки непомірно великі суми потребуватимуть пенсійна система і система медичної допомоги. [5]

3 іншого боку, у слабо розвинутих країнах показники народжуваності значно вищі, і там населення продовжує стрімко зростати, але водночас поступово збільшується частка неосвіченого населення, оскільки надати дітям нормальну освіту у цих країнах може далеко не кожен. Тому старіння нації у високорозвинутих країнах на фоні зростання населення у слабо розвинутих призводить до зменшення частки освіченого населення, та у майбутньому може призвести до втрати багатьма країнами своїх провідних позицій.

Через це загроза депопуляції змушує уряди багатьох країн приділяти все більше і більше уваги процесу народжуваності, як основному чиннику, що визначає режим відтворення населення. Переважно у всіх розвинених країнах світу більш або менш застосовуються заходи економічного стимулювання народжуваності, але вони, по-перше, не дають бажаного ефекту, а подруге, піддаються критиці.

Зусилля держави щодо розв'язання проблем демографічного розвитку певним чином можна оцінити шляхом аналізу витрачання бюджетних коштів на ті чи інші програми. До державних видатків, що мають демографічну спрямованість, можна віднести такі: на соціальний захист сім'ї, дітей та молоді на допомогу у вирішення житлового питання. Серед програм демографічної спрямованості значну роль відіграють державні допомоги сім'ям з дітьми. Це є справді важливим напрямом витрачання державних коштів на соціальний захист, зважаючи на високі показники бідності сімей 3 дітьми. [4]

Загалом на можливості демографічної політики (у традиційному іiі розумінні) погляди багатьох фахівців не $є$ однозначними. Більшість 3 них не надто оптимістичні щодо оцінки впливу економічного стимулювання народжуваності на збільшення чисельності населення. Вони переконані у тому, що чисельність населення продовжуватиме зменшуватися навіть за умови впровадження щедрих допомог з боку держави на народження та виховання дітей, оскільки як стверджує український демограф Е. Лібанова “демографічний потенціал населення $\epsilon$ абсолютно вичерпаним”. [7]

Також варто додати, що стимулювання народжуваності шляхом грошової допомоги 3 боку держави, може досить дорого обійтися державі і у подальшому спричинити серйозні економічні проблеми.

Разом 3 тим деякі науковці більш оптимістично ставляться до перспектив впливу на народжуваність. Так, I. Курило вважає що певне піднесення народжуваності можна очікувати від зростання добробуту громадян, внаслідок зростання рівня продуктивності праці. [6]

Але разом 3 тим зростання продуктивності праці потребує більшого залучення населення країни до економічного життя. А це може створити певні перешкоди до зростання народжуваності, адже майбутні батьки будуть зайняті у виробництві і часу на виховання дітей у них не буде.

Зокрема, згідно з чинним законодавством, в Україні діють такі види допомоги сім'ям 3 дітьми: по вагітності та пологах, при народженні дитини, по догляду за дитиною до досягнення нею трирічного віку, на дітей, що перебувають під опікою та піклуванням, на дітей одиноким матерям, а також допомога малозабезпеченим сім'ям 3 дітьми. [4]

Проте такі заходи, більш-менш здатні виконувати функції захисту від бідності, майже не впливають на народжуваність. Як свідчать дані обстежень умов життя домогосподарств в Україні, незважаючи на постійне зростання розмірів допомог, радикальної зміни матеріального становища сімей 3 дітьми не відбувається, не впливають вони також і на ситуацію з народжуваністю. [4]

Іншим способом збільшення чисельності населення певної країни $є$ стимулювання міграційних поповнень. 3 одного боку, міграційні процеси i міграційна політика не $\epsilon$ суто демографічними питаннями, оскільки чинниками міграції $є$ економічний розвиток та становище на ринку праці. Проте міграційний рух впливає на зміни демографічного складу населення як країндонорів, так і країн-реципієнтів.

Тому міграційну політику можна розглядати як інструмент демографічної політики. Але він також $\epsilon$ досить суперечливим, оскільки збільшення кількості мігрантів у країні може спричинити конфліктні ситуації між представниками різних національностей, пов'язаних 3 міжетнічними, міжрелігійними та міжкультурними відносинами. [4]

Висновки i перспективи подальших досліджень. Підсумовуючи все вищесказане, можна зробити висновок, що демографічна криза 
є невід'ємною складовою високорозвинених країн. Оскільки, у цих країнах поступово впродовж їх розвитку сформувалася сприятлива обстановка як з соціального, так і з економічного боку для погіршення демографічної ситуації. Ця проблема потребує негайного вирішення, але воно повинне бути прийняте правильно i 3 урахуванням всіх можливих наслідків, що може спричинити дане рішення.

Зокрема, якщо держава бажає економічного стимулювання збільшення рівня народжуваності, то вона повинна враховувати власні фінансові можливості, щоб не погіршити власні позиції на економічному просторі. 3 іншого боку, якщо країна хоче збільшити демографічні показники за рахунок мігрантів, то можливе загострення певних міжетнічних, міжкультурних суперечок між представниками різних країн, чи навіть дискримінація одних іншими.

Тому покращення демографічних показників $\epsilon$ складним та суперечливим питанням. Однак, на нашу думку, потрібно формувати думку про інститут сім’ї у кожного жителя країни 3 дитинства, толерантне ставлення до представників інших націй, i водночас допомагати слабо розвинутим країнам, щоб уникнути проблеми зростання неосвіченого населення.

\section{ПЕРЕЛІК ВИКОРИСТАНИХ ДЖЕРЕЛ}

1. Борисов В.А. Демографія - М.: Видавничий дім NOTABENE. - 2001. -272 с.

2. Дорошенко Л. С. Демографія: Практикум. - К.: МАУП, 2007. - 80 с.

3. Власенко Н. О. Демографічні тенденції сучасного суспільства // Публічне управління в Україні: стратегія реформ: збірник тез науково-практичної конференції за підсумками стажування слухачів. - 28 вересня, 2016 р c. $1-5$

4. Колот А. Глобальні трансформації індивідуалізованого суспільства: наслідки та уроки / А. Колот // Міжнародна економічна політика. -2014. - №1 - С. 5-22

5. Макарова О. В. Демографічна політика: сучасні реалії та перспективи // Демографія та соціальна економіка: науково-економічний та суспільно-політичний журнал. - 2007. -Т.1, №1. - с. 3-11

6. Курило І. О. Тенденції народжуваності в Україні у контексті подальшої трансформації суспільства // Демографія та соціальна економіка. Науково-економічний та соціально-політичний журнал -2006. - №1 - с.3845

7. 3 виступу чл.-кор. НАНУ д.е.н. Е. Лібанової на “круглому столі” з демографічних питань, Київ. - червень 2016 р. / [Електронний ресурс] - Режим доступу: www.vox.com.ua

8. Американська психологічна асоціація [Електронний ресурс] - Режим доступу до ресурсу: http://www.apa.org/topics/sex/

9. Глобальні проблеми людства. - М .: Изд-во МГУ, 2006. - 264 с. / [Електронний ресурс] - Режим доступу до ресурсу: MirKnig.com

\section{REFERENCES}

1. Borysov V. A. (2001). Demohrafiya [Demography]. Moscow: NOTABENE. [In Ukrainian]

2. Doroshenko L. S. (2007). Demohrafija: praktykym. [Demography: workshop]. Kiev: MAUP. [In Ukrainian]

3. Vlasenko N. O. (2016). Demohrafichni tendentsiyi suchasnoho suspil'stva [Demographic trends of modern society]. Publichne upravlinnya $v$ Ukrayini: stratehiya reform: zbirnyk tez naukovo-praktychnoyi konferentsiyi za pidsumkamy stazhuvannya slukhachiv. - Public administration in Ukraine: the strategy of reforms: a collection of theses of the scientific and practical conference on the basis of practise of students. [In Ukrainian]

4. Kolot A. (2014) Hlobal'ni transformatsiyi indyvidualizovanoho suspil'stva: naslidky ta uroky. [Global transformations of an individualized society: effects and lessons]. Mizhnarodna ekonomichna polityka. - Internatioal economic policy. [In Ukrainian]

5. Makarova O. V. (2007) Demohrafichna polityka: suchasni realiyi ta perspektyvy. [Demographic policy: modern realities and perspectives]. Demohrafiya ta sotsial'na ekonomika: naukovo-ekonomichnyy ta suspil'no-politychnyy zhurnal. - Demography and social economics: a scientific-economic and socio-political journal. P. 1. №1. [In Ukrainian]

6. Kurylo I. O. (2006) Tendentsiyi narodzhuvanosti v Ukrayini u konteksti podal'shoyi transformatsiyi suspil'stva. [Trends in birth rate in Ukraine in the context of further transformation of society]. Demohrafiya ta sotsial'na ekonomika. Naukovo-ekonomichnyy ta sotsial'no-politychnyy zhurnal. - Demography and Social Economy. ScientificEconomic and Socio-Political Magazine. №1.

7. Z vystupu chl.-kor. NANU d.e.n. E. Libanovoyi na "kruhlomu stoli" z demohrafichnykh pytan'. [From the speech, Corr. National Academy of Sciences E. Libanova at the "round table" on demographic issues]. Retrieved from: www.vox.com.ua [In Ukrainian]

8. Amerykans'ka psykholohichna asotsiatsiya. [American Psychological Association]. Retrieved from: http://www.apa.org/topics/sex/ [In Ukrainian]

9. Hlobal'ni problemy lyudstva. [Global problems of humanity]. Retrieved from: MirKnig.com

Одержано 14.03. 2018 р. 